University of Rhode Island

DigitalCommons@URI

The Rhode Island Current Conditions Index

Economics

$11-2014$

\title{
Rhode Island Current Conditions Index - November 2014
}

Leonard Lardaro

University of Rhode Island, lardaro@uri.edu

Follow this and additional works at: https://digitalcommons.uri.edu/ricci

Part of the Econometrics Commons

Terms of Use

All rights reserved under copyright.

\section{Recommended Citation}

Lardaro, Leonard, "Rhode Island Current Conditions Index -- November 2014" (2014). The Rhode Island Current Conditions Index. Paper 120.

https://digitalcommons.uri.edu/ricci/120

This Article is brought to you for free and open access by the Economics at DigitalCommons@URI. It has been accepted for inclusion in The Rhode Island Current Conditions Index by an authorized administrator of DigitalCommons@URI.For more information, please contact digitalcommons-group@uri.edu. 


\title{
CURRENT CONDITIONS
}

\section{LEONARD LARDARO, URI}

\author{
Available Online: http:/ / www .Ilardaro.com/ current.htm \\ Blog: http:/ / rieconomy.blogspot.com \\ Twitter: @ladardo
}

VOL XXI

NUMBER 12

NOV 2014
For a while, hope sprung eternal. It appeared that we might be witnessing the beginning of an ongoing acceleration in the pace of economic during the third quarter. That lasted all the way until we began receiving data from the fourth quarter. It is surprising, and extinguished that assessment. Last month, we saw the Current Conditions Index for October fall from its value of 75 during each month of the third quarter to 58. But there was a possible explanation for the decline that was related to the "mystery decline" in payroll employment for October that very likely affected one of the CCl's indicators. Assuming that to be the case, we could view the October $\mathrm{CCl}$ value as 67 , not quite as good as third quarter values, but among the highest of the 2014 values nonetheless. Then along comes the November data, where there are no obvious exceptions to take account of. The November $\mathrm{CCl}$ value was 67 , still good, but once again inconsistent with the acceleration hypothesis. Furthermore, both fourth quarter values convincingly end the short-lived period where we had begun to match or exceed year-earlier CCl values.

At this point, it is safe to conclude that in spite of accelerating national economic activity, Rhode Island's recovery has failed its first test of becoming more broadly based, at least statistically So, as we move further into the fourth quarter, the lingering question of whether our state's economic performance is decoupling from the accelerating national economy remains.

In November, two of the five leading indicators contained within the Current Conditions Index failed to improve. This is not necessarily as bad as it might sound, for each had very difficult "comps" to beat from last November. Total Manufacturing Hours,

\begin{tabular}{|l|r|r|}
\hline \multicolumn{3}{|c|}{ CCI Indicators - \% Change } \\
\hline Government Employment & -0.5 & \\
\hline US Consumer Sentiment & 18.5 & Y \\
\hline Single-Unit Permits & -23.8 & \\
\hline Retail Sales & 6.6 & $\mathbf{Y}$ \\
\hline Employment Services Jobs & $\mathbf{1 . 0}$ & $\mathbf{Y}$ \\
\hline Priv. Serv-Prod Employment & 1.4 & $\mathbf{Y}$ \\
\hline Total Manufacturing Hours & -2.7 & \\
\hline Manufacturing Wage & -4.0 & \\
\hline Labor Force & $\mathbf{0 . 4}$ & $\mathbf{Y}$ \\
\hline Benefit Exhaustions & -23.4 & $\mathbf{Y}$ \\
\hline New Claims & $-\mathbf{8 . 4}$ & $\mathbf{Y}$ \\
\hline Unemployment Rate (change) & -2.3 & $\mathbf{Y}$ \\
\hline \multicolumn{2}{|c|}{ Y = Improved Value } \\
\hline
\end{tabular}

which measures strength in our manufacturing sector, fell for the third consecutive month, this time at a greater rate $(-2.7 \%)$. Last November, however, this indicator had risen at an almost 7 percent rate, an extremely difficult hurdle to exceed. The deterioration in its growth rate has been accelerating since June. Along with this, the Manufacturing Wage declined yet again, for the ninth consecutive time, by difficult to believe 4 percent. Single a bit disappointing, how quickly the fourth quarter data

-Unit Permits, a very volatile indicator that reflects new home construction, declined for the third time in four months, by 23.8 percent. Viewed along with our state's manufacturing performance in November, the momentum provided by Rhode Island's goods-producing sector has clearly moderated.

Employment Service Jobs, which includes temporary employment and is a prerequisite to employment growth, rose in November $(+1.0 \%)$, following the decline last month that ended a string of three consecutive increases. New Claims, a leading labor market indicator, fell by 8.4 percent in November, its eighth improvement in the last nine months, perhaps the brightest spot of this month's performance. Finally, US Consumer Sentiment rose sharply once again in November $(+18.5 \%)$, its fourth increase following three consecutive declines.

Retail Sales remained strong in November, increasing by 6.6 percent compared to a year ago. This indicator has now improved for ten of the last twelve months. Private ServiceProducing Employment rose by 1.4 percent in November, the first acceleration in its growth rate for the last four months. Not surprisingly, Government Employment failed to improve once again. For November, it declined by 0.5 percent, falling just below 60,000 . Benefit Exhaustions, which reflects longer-term unemployment, fell 23.4 percent relative to a year ago. November marked the seventh double-digit improvement for this indicator in the last eight months.

Finally, Rhode Island's Labor Force rose by 0.4 percent versus a year ago. On a monthly basis, this indicator has declined every month since June. Along with this, our Unemployment Rate fell to 7.1 percent, now the fourth highest nationally.

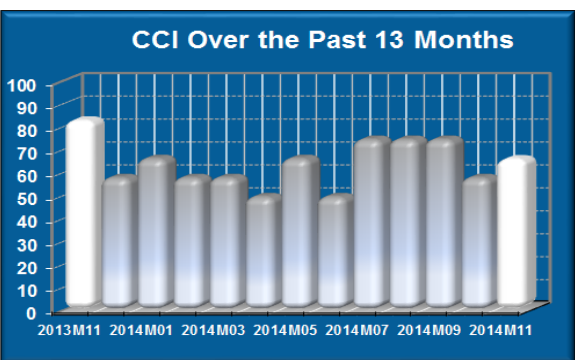

DLT NOV Employment (SA, Y/Y)

Gain 7,500

Loss 1,700

\section{THE BOTTOM LINE}

"The" question of the fourth quarter is whether the pace of Rhode I sland's recovery will keep pace with the accelerating national economy. Gauging this has not been as easy as one might think, since there have been a few data difficulties and several atypical "comps" along the way. So, while it remains uncertain whether the pace of our recovery will eventually accelerate, it is at least safe to say that Rhode Island's recovery is continuing, albeit less broadly based than we would like. The improving national economy and declining energy prices can only benefit our state's recovery, hopefully causing its pace to move more in line with the national economy.

\begin{tabular}{|l|l|l|l|l|l|l|l|l|l|l|l|l|l|}
\hline & & Jan & Feb & Mar & Apr & May & J un & J ul & Aug & Sep & Oct & Nov & Dec \\
\cline { 2 - 25 } & 2013 & 75 & 67 & 83 & $83 \uparrow$ & $75 \downarrow$ & $83 \uparrow$ & 83 & 67 & $75 \uparrow$ & 75 & $83 \uparrow$ & $58 \downarrow$ \\
\cline { 2 - 14 } & 2014 & $67 \downarrow$ & 58 & 58 & $50 \downarrow$ & 67 & 50 & 75 & 75 & 75 & 58 & 67 &
\end{tabular}

